Bangladesh J. Pl. Breed. Genet., 27(1): 9-16, 2014

\title{
GENETIC DIVERSITY IN ADVANCED GENERATION OF VEGETABLE PEA
} (Pisum sativum L.)

\author{
A. Siddika, A. K. M. Aminul Islam*, M. G. Rasul, M. A. K. Mian and J. U. Ahmed ${ }^{1}$ \\ Department of Genetics and Plant Breeding \\ ${ }^{1}$ Department of Crop Botany \\ Bangabandhu Sheikh Mujibur Rahman Agricultural University \\ Gazipur 1706, , Bangladesh \\ * Corresponding author (pulak292003@gmail.com)
}

\begin{abstract}
Twenty five advanced lines among them twelve lines obtained from the cross between Edible Podded Pea and IPSA Motorsuty-1, nine obtained from the cross between Local White and IPSA Motorsuty-3 and five parental lines were included to measure genetic diversity. The field experiment was conducted at the research farm, Bangabandhu Sheikh Mujibur Rahman Agricultural University, Gazipur, Bangladesh. Analysis of variance showed significant differences among the genotypes for all characters. Multivariate analysis based 14 agronomic characters indicated that the 26 genotypes fell into five distant clusters. Fifty percent germination was found to be contributed maximum towards the total divergence. The inter cluster $\left(\mathrm{D}^{2}\right.$ values) distance was maximum between cluster I and cluster II and intra-cluster distance was in cluster III. Cluster V comprising five genotypes, namely, G11, G14, G21, G22, G25 and scored first position for $50 \%$ germination, pod per plant, 100 green seed weight and seed yield per plant (6.02). Genotypes belonging to the cluster I, II and V having greater inter cluster distance and higher cluster means for various characters could be recommended for inclusion in future breeding program as they are expected to produce good segregates.
\end{abstract}

Keywords: vegetable pea, genetic divergence, $\mathrm{D}^{2}$ statistics, seed yield

\section{INTRODUCTION}

Pea has a wide range of agricultural and horticultural uses. The green seeds are used as fresh, frozen or canned vegetables and the mature dry seeds are used as dhal. It is grown on a wide range of soil types ranging from light sandy to heavy clayey soils. In recent years the value of peas for fodder purposes has increased (its green matter contains 14 to $24 \%$ proteins, average $16 \%$ ) as well as its value as a vegetable crop (green peas are the high protein-containing vegetable with a protein content of 6-7 \% on the fresh weight basis). The protein of peas contains all the essential amino acids important for the normal activity of living organisms. The fractional composition is also favorable, the most easily assimilated water soluble protein from mature pea seeds varies from 36 to $87 \%$ and in the green matter from 65 to $82 \%$ (Smirnova-Ikonnikova, 1960). There is a shortage of off-season vegetable in Bangladesh, green pea can be considered as vegetable crop as it need smaller area of land and can also be grown without competition with cereal crops.

\footnotetext{
${ }^{1}$ Department of Crop Botany, Bangabandhu Sheikh Mujibur Rahman Agricultural University, Gazipur 1706, Bangladesh.
} 
In recent years, due to the need for intensive land utilization aiming at obtaining two to three crops a year from the same piece of land, new trends of breeding have to developed in our country for higher number of functional nodules on the pea roots, the activity of which makes this once of the nitrogen fixing crop (Rudnicki and Wenda 2002).

The most important tasks for a pea breeding are development of high yielding varieties with stable productivity, sufficiently good resistance to diseases and unfavorable environmental conditions, different maturing types, high rate of organic matter accumulation during the initial phases of growth, sufficiently high intensity of photosynthesis, increases in protein content, essential amino acids and favorable rations among them (Gritton, 1986; Abdou et al., 1999; Tiwari et al., 2001). For all of these, genetic diversity has been considered as an important factor which is essential prerequisite for obtaining high yielding progenies and to select suitable types among the segregating populations (Aher et al., 1998; Backiyarani et al., 2000). The quantification of genetic diversity through biometrical procedure made it possible to choose genetically diverse parents for a successful hybridization program. Moreover, evaluation of genetic diversity is important to know the source of genes for a particular trait within the available germplasm. Better knowledge on genetic diversity or genetic similarity could help to sustain long term selection gain (Chowdhury et al., 2002). There was no common criterion for selection of genotypes on the basis of specific objectives among the plant materials. Assessment of variability available in the segregating population of pea may help to select suitable lines for the development of vegetable pea (Arunachalam, 1981). The research work aims to study genetic diversity among the advanced lines of vegetable pea which may help to select suitable types for commercial cultivation.

\section{MATERIALS AND METHODS}

The experiment was conducted at the field laboratory, Department of Genetics and Plant Breeding, Bangabandhu Sheikh Mujibur Rahman Agricultural University (BSMRAU), Bangladesh during the winter season (November to March). The experimental materials were included 5 varieties (IPSA-1, IPSA-2, IPSA-3, BARI-1 and Local white), 12 advanced lines obtained from cross Edible Podded Pea $\times$ IPSA Motorsuty-1 (L-19, L-95, L-128, L-227, L-145, L-195, L-252, L-20, L-92,L-160, L-141 and L-72) and 9 advanced lines obtained from cross Local white $\times$ IPSA Motorsuty-3 \{L-120, L-20, L-105, L-247, L-26, L-244, L-142 (tall), L-142 short) and L-155\} designated from G1 to G26. The seeds were sown in the field and seedlings were emerged five to twelve days after seed sowing. The experiment was conducted using the Randomized Complete Block Design (RCBD) with three replications. The unit plot size was $50 \mathrm{~m} \times 4 \mathrm{~m}$ with row to row distance $50 \mathrm{~cm}$ and plant to plant distance $20 \mathrm{~cm}$. Each plot consisted of 78 rows and plot to plot distance was 0.5 meter. The unit plots were fertilized with cow dung, urea, TSP and MP @ $10 \mathrm{t}, 45 \mathrm{~kg}, 62.5 \mathrm{~kg}, 50 \mathrm{~kg}$ per ha, respectively (BARI, 2003). The entire cow dung, TSP, MP and half of the urea were applied at the time of final land preparation. The remaining half of urea was applied as top dressing in two installments. First top dressing was done at 21 days after and second at 42 days after sowing.

Data were noted on individual plant basis from ten randomly selected competitive plants on days to $50 \%$ germination, days to first Flowering, days to $50 \%$ flowering, days to $100 \%$ flowering, days to $50 \%$ harvest, branches per plant, plant height, pod per plant, pod length, pod breadth, seeds per pod, 100 green seed weight, seed yield per plant, seed yield per plot. Multivariate analysis viz, principal component analysis (PCA) (Mahalanobis, 1936; Jager et al., 1983), principal coordinate analysis 
(PCO) (Digby et al. 1989), canonical variate analysis (CVA) and Cluster analysis (CLSA) using GENSTAT 4.2.

\section{RESULTS AND DISCUSSION}

Multivariate Analysis $\left(\mathrm{D}^{2}\right.$ Statistics)

Principal component analysis

Principal component analysis yielded eigen values of each principal component axes of coordination of genotypes in which the first axes accounted $91.42 \%$ of the total variation among the genotypes, while 10 of these with eigen values above unity accounted for 99.99\% (Table 1).

Table 1. Eigen values and percentage of variation for corresponding 12 component characters in 26 genotypes of pea

\begin{tabular}{l|c|c|c}
\hline Principal Component axis & Eigen & \multicolumn{2}{|c}{ Percentage of } \\
\cline { 3 - 4 } & Values & total variation accounted for & Cumulative \\
\hline 50\% germination & 91.42 & 91.42 & 91.42 \\
First flowering & 5.05 & 5.05 & 96.47 \\
50\% flowering & 1.99 & 1.99 & 98.46 \\
100\% flowering & 0.77 & 0.77 & 99.16 \\
Days to 50\% harvest & 0.41 & 0.41 & 99.57 \\
Branches per plant & 0.18 & 0.18 & 99.75 \\
Plant height & 0.15 & 0.15 & 99.9 \\
Pod per plant & 0.07 & 0.07 & 99.97 \\
Pod length & 0.01 & 0.01 & 99.98 \\
Pod breadth & 0.01 & 0.01 & 99.99 \\
Seeds per pod & 0.00 & 0.00 & 99.99 \\
100 green seed weight & 0.00 & 0.00 & 99.99 \\
Seed yield per plant & 0.00 & 0.00 & 99.99 \\
Seed yield per plot & 0.00 & 0.00 & \\
\hline
\end{tabular}

Table 2. Intra and Inter cluster distances $\left(\mathrm{D}^{2}\right)$ among 26 genotypes of vegetable pea

\begin{tabular}{l|c|c|c|c|c}
\hline Cluster & I & II & III & IV & V \\
\hline I & $\mathbf{0 . 0 0}$ & 29.93 & 24.02 & 16.97 & 22.1 \\
II & & $\mathbf{2 . 8 5}$ & 5.99 & 13.07 & 8.8 \\
III & & & $\mathbf{6 . 6 4}$ & 7.1 & 4.8 \\
IV & & & & $\mathbf{0 . 4 9}$ & 6.82 \\
V & & & & & $\mathbf{1 . 8 3}$ \\
\hline
\end{tabular}

Intra-cluster distance (Table 2) were calculated from these inter genotypic distances (Singh and Choudhary, 2001). The highest intra-cluster distance was 6.64 observed in cluster III, which was composed of ten genotypes, followed by cluster II (2.85) containing 7 genotypes. The intra-cluster distances in all the five clusters were lower than the inter cluster distances and which indicated that genotypes within the same cluster were closely related.

\section{Non-hierarchical Clustering}

With the application co-variance matrix for non-hierarchical clustering, 26 pea genotypes were grouped into five different clusters. Composition of different clusters with their corresponding genotypes included in each cluster is presented in Table 3. From Table 3, cluster III had maximum ten genotypes (G4, G8, G10, G12, G15, G16, G18, G19, G24, 
G26) followed by cluster II (G1, G2, G3, G7, G9, G13, G20), cluster V (G11, G14, G21, G22, G25) and cluster IV (G5, G17, G23). Cluster I comprises with a single genotype G6. Satyawan et al. (2004) reported 9 clustering in field pea, Singh and Singh (2003) studied genetic divergence for 10 traits and had 11 clusters and Vikas and Singh (1999) had 9 clusters for 45 pea genotypes.

Table 3. Distribution of 26 genotypes of vegetable pea in different clusters

\begin{tabular}{|c|c|c|}
\hline Cluster & $\begin{array}{l}\text { Total no. of } \\
\text { genotypes }\end{array}$ & Genotypes \\
\hline I & 1 & G6 (L-19) \\
\hline II & 7 & $\begin{array}{l}\text { G1(IPSA-1), G2(IPSA-2), G3(IPSA-3), G7(L-95), G9(L-227), } \\
\text { G13(L-20), G20(L-105) }\end{array}$ \\
\hline & & $\begin{array}{l}\text { G4(BARI-1), G8(L-128), G10(L-145), G12(L-252), G15(L-160), } \\
\text { G16(L-141), G18(L-120), G19(L-20), G24(L-142 (tall)), G26(L- }\end{array}$ \\
\hline III & 10 & 155) \\
\hline IV & 3 & $\begin{array}{l}\text { G5(Local white), G17(L-72), G23(L-244), } \\
\text { G11(L-195), G14(L-92), G21(L-247), G22(L-26), G25(L-142 }\end{array}$ \\
\hline V & 5 & short) \\
\hline
\end{tabular}

\section{Canonical variate analysis}

Canonical Variate analysis was done to compute the inter-cluster Mahalanobis's $\mathrm{D}^{2}$ values. The intra and inter-cluster distance $\left(\mathrm{D}^{2}\right)$ values are presented in Table 2. Results indicated that the highest inter-cluster distance was observed between clusters I and II (29.93) followed by I and III (24.02) and I and V (22.1). The higher inter-cluster distances between these clusters indicate to obtain wide spectrum variability of population. However, the highest inter-cluster distance was observed between clusters I and II indicated the genotypes in these clusters were diverged than those of other clusters. The lowest inter-cluster distance was observed between the clusters III and V (4.8), suggesting a close relationship among the genotypes included within these clusters. The intra-cluster distance varied from 0.00 to 6.64 , maximum for cluster III that was composed of 10 genotypes of diverse origin, while the minimum distance was found in cluster I that was composed of one genotype. Statistical distances represent the index of genetic diversity among the cluster. The inter-cluster distances were larger than the intracluster distances which indicated wider genetic diversity among the genotypes of different groups.

\section{Cluster mean value}

An attempt was made to characterize the individual genotype in respect of their mean values for different characters with a view to get idea that weather genotypes having similar characteristics could be disseminated. The mean values for all the 14 characters along with the marking of the highest $(\mathrm{H})$ and the lowest $(\mathrm{L})$ for each of the cluster are presented in Table 4. The data revealed that different clusters exhibited different mean values for almost all the characters. Cluster I constituted a single genotype, namely G6 produced the highest mean for seeds per pod (5.4) and seed yield per plot (555.17). But the lowest mean for first flowering (37), 50\% flowering (41.33), branches per plant (1.53), pods per plant (5.2). That means it was an early flowering genotype.

Seven genotypes viz. G1, G2, G3, G7, G9, G13, G20 established cluster II. The genotypes of these cluster produced the highest mean for first flowering (42.33), 100\% flowering (59.14), pod breadth (12.74). Low yielder and short-duration genotypes within a cluster was also reported by Singh and Gumber (1996) in pigeon pea. The lowest mean 
values for seeds per pod (3.75). The genotypes of cluster III, namely G4, G8, G10, G12, G15, G16, G18, G19, G24, G26 produced the highest mean values for 50\% flowering (53.9), days to 50\% harvest (80.07), branches per plant (1.73) pod length (70.56) and the lowest mean values for pod breadth (12.14). It was observed that cluster IV constitute 3 genotypes (G5, G17, G23) produced the highest mean for plant height (99.05) and produced the lowest mean for 50\% germination (5.22), pod length (60.21), 100 green seed weight (18.1), seed yield per plant (4.47). Cluster V comprising five genotypes, namely, G11, G14, G21, G22, G25 and scored first position for 50\% germination (6.8), pod per plant (6.29), 100 green seed weight (28.5) seed yield per plant (6.02) and the lowest mean for $100 \%$ flowering (47.13), plant height (51.99), days to $50 \%$ harvest (72.27) and the second lowest position for first flowering (38.27) and 50\% flowering (44.93). Singh and Gumber (1996) also got cluster having high seed yield and number of pods/plant in pigeon pea (Cajanus cajan) genotypes.

Table 4. Cluster mean values of 14 characters of 26 genotypes in vegetable pea

\begin{tabular}{l|c|c|c|c|c}
\hline \multirow{2}{*}{ Character } & \multicolumn{5}{|c}{ Cluster } \\
\cline { 2 - 6 } & I & II & III & IV & V \\
\hline 50\% germination & 5.67 & 6.19 & 6.03 & $5.22(\mathrm{~L})$ & $6.80(\mathrm{H})$ \\
First flowering & $37.00(\mathrm{~L})$ & $42.33(\mathrm{H})$ & 40.93 & 40.44 & 38.27 \\
$50 \%$ flowering & $41.33(\mathrm{~L})$ & 52.05 & $53.9(\mathrm{H})$ & 49.00 & 44.93 \\
$100 \%$ flowering & 54.00 & $59.14(\mathrm{H})$ & 57.53 & 55.44 & $47.13(\mathrm{~L})$ \\
Days to 50\% harvest & 77.67 & 77.48 & $80.07(\mathrm{H})$ & 79.67 & $72.27(\mathrm{~L})$ \\
Branches per plant & $1.53(\mathrm{~L})$ & 1.72 & $1.73(\mathrm{H})$ & 1.58 & 1.60 \\
Plant height & 96.43 & 64.2 & 88.98 & $99.05(\mathrm{H})$ & $51.99(\mathrm{~L})$ \\
Pod per plant & $5.20(\mathrm{~L})$ & 6.24 & 6.15 & 5.95 & $6.29(\mathrm{H})$ \\
Pod length & 64.45 & 68.93 & 70.56 & $60.21(\mathrm{~L})$ & $68.49(\mathrm{H})$ \\
Pod breadth & 12.34 & $12.74(\mathrm{H})$ & $12.14(\mathrm{~L})$ & 12.44 & 12.62 \\
Seeds per pod & $5.40(\mathrm{H})$ & $3.75(\mathrm{~L})$ & 4.61 & 5.06 & 3.97 \\
100 green seed weight & 21.53 & 20.61 & 20.17 & $18.10(\mathrm{~L})$ & $28.5(\mathrm{H})$ \\
Seed Yield per plant & 5.28 & 4.49 & 5.28 & $4.47(\mathrm{~L})$ & $6.02(\mathrm{H})$ \\
Seed Yield per plot & $555.17(\mathrm{H})$ & $129.24(\mathrm{~L})$ & 220.92 & 350.89 & 262.67 \\
\hline
\end{tabular}

The ranges 5.22 to 6.80 of variability were recorded for $50 \%$ germination among all the five clusters. Cluster I mainly early flowering genotype where as it produced the lowest mean values for first flowering, 50\% flowering, branches per plant and pods per plant. Cluster II has early first flowering, $100 \%$ flowering, the widest pod and the lowest seeds per pod. The genotypes belonging to the cluster III were late maturing type because they possessed the highest mean values for 50\% flowering and days to $50 \%$ harvest. They also possess highest mean values for branches per plant, pod length and the lowest mean values for pod breadth. The genotype belongs to the cluster IV were tall and they geminate early. The genotypes of the cluster $\mathrm{V}$ are important for early maturing types because they possessed the lowest mean values for days to $50 \%$ harvest and the second lowest mean values for $50 \%$ flowering. It also possessed the highest mean values for pods per plant, 100 green seed weight and seed yield per plant. To develop high yielding varieties along with early maturing type these groups can be used in hybridization program.

\section{Contribution of characters toward divergence of the genotypes}

Contribution of characters towards the divergence obtained from canonical variate analysis is presented in Table 5. In this method vectors was calculated to represent the varieties in the graphical form (Rao, 1952). This is helpful in cluster analysis as it 
facilitates the study of group constellations and also serves as a pictorial representation of the configuration of various groups. The absolute magnitude of the coefficients in the first two canonical vectors also reflects to a great extent, the importance of the characters for primary and secondary differentiation. The character, which gives high absolute magnitude for vector 1 , is considered to be responsible for primary differentiation. Likewise, the characters, which give higher absolute magnitude for vector 1 is considered to be responsible for secondary differentiation. If the same character gives equal magnitude for both the vectors then the character is considered responsible for primary as well as secondary differentiation (Rao and Singh, 1994; Devendra et al., 2001).

Table 5. Latent Vectors for 14 principle component characters of 26 genotypes in pea

\begin{tabular}{l|c|c|l|c|c}
\hline Character & Vector 1 & Vector 2 & Character & $\begin{array}{c}\text { Vector } \\
1\end{array}$ & $\begin{array}{c}\text { Vector } \\
2\end{array}$ \\
\hline 50\% germination & 0.14 & -1.14 & Pod per plant & -1.48 & -0.94 \\
First flowering & 0.06 & -0.05 & Pod length & 0.26 & -0.03 \\
50\% flowering & -0.26 & 0.13 & Pod breadth & -0.04 & 0.20 \\
100\% flowering & 0.04 & 0.11 & Seeds per pod & -0.77 & 0.40 \\
Days to 50\% harvest & 0.03 & -0.03 & 100 green seed weight & -0.31 & -0.07 \\
Branch per plant & 0.92 & 2.31 & Seed yield per plant & 0.52 & 0.18 \\
Plant height & -0.01 & 0.01 & Seed yield per plot & 0.07 & -0.01 \\
\hline
\end{tabular}

In vector $1\left(\mathrm{Z}_{1}\right)$ obtained from PCA, the important characters responsible for genetic divergence in the axis of differentiation were branches per plant $(0.92), 50 \%$ germination $(0.14)$, seed yield per plant $(0.52)$, pod length $(0.26)$, first flowering $(0.06)$, $100 \%$ flowering (0.04), days to $50 \%$ harvest $(0.03)$, seed yield per plot $(0.07)$. In vector 2 $\left(\mathrm{Z}_{2}\right)$, the second axis of differentiation, $50 \%$ flowering $(0.13), 100 \%$ flowering $(0.11)$, branches per plant (2.31), plant height $(0.01)$, pod breadth $(0.20)$, seeds per pod $(0.40)$, seed yield per plant $(0.18)$ were important because all these characters had positive signs. On the other hand 50\% flowering, plant height, pods per plant, pod breadth, seeds per pod, 100 seed weight possessed the positive sign in the first axis of differentiation and $50 \%$ germination, first flowering, days to $50 \%$ harvest, pods per plant, pod length, 100 seed weight, seed yield per plot possessed negative signs in the second axis of differentiation that means it had minor role in the genetic diverse. $100 \%$ flowering, Branches per plant, seed yield per plant had positive signs in both the vectors, which indicated they were the important component characters having higher contribution to the genetic divergence among the materials studied (Narendra and Kumar, 1997, Sharma and Mishra, 1997).

Backiyarani et al. (2000) evaluated that Single plant yield, harvest index and earliness in flowering together accounted for $80 \%$ of the total genetic divergence of cowpea. Ushakumari et al. (2000) assessed that the highest contributions towards divergence were recorded for plant height, seeds per pod, number of branches per plant, number of pods per cluster and pod length of cowpea. Manikannan et al. (2000) estimated that the photosynthetic rate $(47.83 \%), 100$ seed weight $(11.83 \%)$ and SLW (11.18) contributed more to the total genetic divergence in the 31 genotypes of blackgram. According to Rao and Jain, (1996) the percentage of contribution of individual character towards genetic diversity revealed that 100 -seed weight and plant height are the major characters contributing to genetic diversity in the chickpea. Pod yield and seeds per pod were important contributors to genetic divergence (Ram et al., 1997; Sureja and Sharma, 2000). Santos et al. (1997) found length of the main branch, 100 -seed weight and pod length were the most important characters to affect divergence 
in Vigna unguiculata. Manivannan et al. (1999) measured genetic diversity of thirty mungbean (Vigna mungo L.) genotypes by grouping them into six clusters. The pattern

of $\mathrm{D}^{2}$ clusters demonstrated that geographical distribution in mungbean was not related to genetic diversity. Among the characters, number of pods/cluster, number of pods/plant and number of clusters/plant contributed maximum towards the genetic divergence.

\section{Selection of genotypes for future hybridization program}

Genotypes were to be selected on the basis of specific objectives. No common criterion was considered for the selection of genotypes. Genotypically distant parents usually able to produce higher heterosis (Falconer 1960; Moll et al. 1962; Ramanujam et al., 1974; Ghaderi et al., 1984). The genotypes belonging to the distance clusters could be used in hybridization program for obtaining a wide spectrum of variation among segregates. Similar reports were also made by Bansal et al. (1999) and Singh et al. (1996). The genotypes viz. $\mathrm{G}_{1}, \mathrm{G}_{2}, \mathrm{G}_{3}, \mathrm{G}_{6}, \mathrm{G}_{7}, \mathrm{G}_{11}, \mathrm{G}_{13}, \mathrm{G}_{19}, \mathrm{G}_{20}, \mathrm{G}_{21}, \mathrm{G}_{22}$ belonging to cluster I, II and $\mathrm{V}$ having greater cluster distance and higher cluster means for various characters could be recommended for inclusion in hybridization program as they are expected to produce good segregants. Thus it could be suggested that crossing should be made between genotypes belonging to this distance clusters for higher heterotic response. In the present study the inter-cluster distances between cluster II and I with other cluster suggesting crossing the genotypes of cluster II and I with desirable genotypes of other clusters would express heterosis. Sinha et al. (1991) reported that selection of parents from distantly placed clusters exhibited significant high heterotic segregants.

\section{References}

Abdou, A. B. A., M. F. Mohamed and N. M. Kandeel. 1999. Breeding implications on cultivarselection in garden pea (Pisum sativum L.) towards enhancing earliness and pod-yield. Assiut J. Agril. Sci. 30 (3): 117-132.

Aher, R. P, J. S. Salunke, G. C. Shinde and N. S. Kute. 1998. Genetic diversity in early pigeon pea, Indian J. Pulse Res. 11 (1): 68-71.

Arunachalam, V. 1981. Genetic distances in plant breeding. Indian J. Genet., 41: 226-236.

Backiyarani, S. N. Nadarajan, C. Rajendra and S. Shanti. 2000 Genetic divergence for physiological traits in cowpea (Vigna unguiculata (L) Walp). Lugume Res. 23 (2): 114117.

Bansal, U. K., R. G. Saini, N. S. Rani and A. Kaur. 1999. Genetic divergence in quality rice. Oryza. 36 (1): 20-23.

BARI. 2003. Krishi Projukti Hatboi (Hand Book on Agro-technology), Bangladesh Agricultural Research Institute. Gazipur 1701, Bangladesh.

Chowdhury, M. A., V. Vandenberg and T. Warkentin. 2002. Cultivar identification and genetic relationship among selected breeding lines and cultivars in chick pea (Cicer arietinum L). Euphytica. 127(3): 317-325.

Chowdhury, M. A., V. Vandenberg and T. Warkentin. 2002. Cultivar identification and genetic relationship among selected breeding lines and cultivars in chick pea (Cicer arietinum L). Euphytica. 127(3): 317-325.

Devendra, P., D. P. Singh. And B. B. Singh .2001. Evaluation of pea germplasm for yield and yield components. Indian J. Pulses Res. 14(2): 148-149.

Digby, P., N. Galway and P. Lane. 1989. Genstat 5, A second course. Oxford Sci. Publication, Oxford. pp 103-108.

Falconer, D.S. 1960. Introduction to quantitative genetics, $1^{\text {st }}$ Edition, Oliver and Bond, London. $304 p$.

Ghaderi, A., M. Shishegar, A. Regai and B. Ehdate. 1984. Multivariate analysis of genetic diversity for yield and its components in mungbean. J. American Soc. Hort. Sci. 104(6): 728-732. 
Gritton, E. T. K. 1986. Pea Bjreeding, pp.283-319. In M. J. Bassett (ed.), Breeding Vegetable crops. AVI Publ. Co. Westport.

Jager, M. I., D. Gerethojones and E. Griffiths. 1983. Components of partial resistance of wheat seedlings to Seporia nodrom. Euhytica. 32: 575-585.

Mahalanobis, P. C. 1936. On the generalized distance in statistics. Proc. Natl. Inst. Sci., India. 2:49-55.

Manikannan, C., S. Jebaraj and S. Ashok. 2000. Genetic divergence in blackgram. J. Pulses Res. 12 (1): 25-29.

Manivannan, N., E. Murugan, P. Viswanathan, K. Sethuraman and C. V. Dhanakodi. 1999. Genetic divergence in urdbean. Indian J. Pulses Res. 12 (1): 25-29.

Moll. R. H., W. S. Salhuana and H. F. Robinson. 1962. Heterosis and genetic diversity in variety crosses of maize. Crop. Sci. 197-198.

Narendra, K. and N. Kumar. 1997. Genetic diversity among chickpea accessions. Indian J. Genetics and Plant Breeding. 57 (1): 87-90.

Ram, S. G., P. Gomathinayagam and R. Rathnaswamy, 1997. Genetic divergence in blackgram. Madras Agril. J. 84 (3): 160-162.

Ramanujam, S., A. S. Tiwari and R. B. Mehra. 1974. Genetic divergence and hybrid performance in mungbean. Theor. Appl. Genet. 25: 211-214.

Rao, C. R. 1952. Advance Statistical Methods in Biometrical Research. John Wiley and Sons. New York

Rao, S. K. and R. K. Singh. 1994. Genetic diversity in elite chickpea genotypes. Agril. Sci. Digest Karnal. 14 (3-4): 153-155.

Rao, S. K. and S. K. Jain 1996. Genotype $\times$ year interaction in the genetic diversity of elite chickpea (Cicer arietinum L.) germplasm. Legume Res. 19 (2): 75-82.

Rudnicki and A P Wenda. 2002. Usefulness of pea cultivars for mixtures with spring cereals cultivated on wheat soil complex. Roslin. 221(6):199-206.

Santos, C. A. F., E. A. Menzes and F. P. Araujo.1997. Genetic diversity in genotypes of cowpea under 2 different environments. Revista Ceres. 44 (251): 35-42.

Satyawan,A., B. P. S. Malik. and R. Kumar. 2004. Variability, correlation and path analysis in field pea (Pisum sativum L.). Haryana. Agril. University. J. Res. 34 (2): 149-153.

Sharma, T. R. and S. N. Mishra. 1997. Genetic divergence and character association studies in cowpea. Corp Res. Hisar. 13 (1): 109-114.

Singh, A. K., S. B. Singh and S. M. Singh. 1996. Genetic divergence in scented and fine genotypes of rice (Oryza sativa L.). Ann. Agril. Res. 17 (2): 163-166.

Singh, G. and S. P. Singh. 2003. Genetic divergence in pea (Pisum sativum L.) Legume Res. 26(2): 131-133.

Singh, R. K and B. D. Choudhary. 2001. Biometrical methods in quantitative genetic analysis. Kalyani Publishers. New Delhi.224-229.

Singh, S. and R. K. Gumber. 1996. Assessment of genetic diversity in basic generations of pigeonpea. International Chickpea and Pigeonpea Newsletter. 3:62-64.

Singh, S. and R. K. Gumber. 1996. Assessment of genetic diversity in basic generations of pigeonpea, International Chickpea and Pigeonpea Newsletter. 3: 62-64.

Sinha, P.K., V.S. Chauhan, K. Prasad and J.S. Chauhan. 1991. Genetic divergence in indigenous upland rice varieties. Indian J. Genet. 51(1): 47-50.

Smirnova-Ikonnikova, M. I. 1960. Khimicheskii sostav zernovykh bobovykh kul'tur (Chemical composition of grain legumes). Zernovye bobovye kul'tury, Moscow, 29-51.

Sureja, A. K. and R. R. Sharma. 2000. Genetic variability and heritability studies in garden pea (Pisum sativum L.). Indian. J. Hort. 57 (3): 243-247.

Tiwari, S. K., H. L. Singh, R. Kumar, H. K. Nigam. 2001. A postmortem of selection parameters in pea (Pisum sativum L.). Crop Res. 2 (2): 237-242.

Ushakumari, R., S. Backiyarani and C. V. Dhanakodi. 2000. Character contribution to diversity in cowpea. Legume Res. 23 (2): 122-125.

Vikas, K. M. and S. P. Singh. 1999. Genetic divergence over environments in pea (Pisum sativum L.). Legume Res. 22 (2): 104-108. 